\title{
Birdwatching Track: Peluang Konservasi Burung di RPH Tambak Ngargoyoso Karanganyar Jawa Tengah
}

\author{
Dewi Puspita Sari' ${ }^{1}$, Siti Fadzillah ${ }^{2}$, Wahyu Trianingsih ${ }^{3}$ \\ ${ }^{1}$ Prodi Pendidikan Biologi Fakultas Keguruan dan Ilmu Pendidikan Universitas Sebelas Maret, Surakarta. \\ Email: dewipuspita@staff.uns.ac.id \\ 2 Prodi Biologi Fakultas Matematika dan Ilmu Pengetahuan Alam Universitas Sebelas Maret, Surakarta. \\ Email:sitifadzillah@student.uns.ac.id \\ 3 Prodi Pendidikan geografi Fakultas keguruan dan Ilmu Pendidikan Universitas Sebelas Maret, Surakarta. \\ Email:wahyutrianingsih@student.uns.ac.id
}

$\begin{array}{ll}\text { Received } & : 21-03-2020 \\ \text { Accepted } & : 01-05-2020 \\ \text { Available online } & : 14-05-2020\end{array}$

\begin{abstract}
ABSTRAK
RPH (Resort Pemangku Hutan) Tambak merupakan daerah hutan yang dikelola oleh Perusahaan Hutan Negara Indonesia (PERHUTANI) BKPH (Bagian Kesatuan Pemangku Hutan) Lawu Utara, KPH (Kesatuan Pemangku Hutan) Surakarta. Lokasi RPH terletak di lereng utara Gunung Lawu tepatnya di dusun Tambak Desa berjo Kecamatan Ngargoyoso merupakan kawasan ekowisata. Pengeloaan kelestarian hutan menjadi hal penting dengan keterlibatan dari pemerintah dan masyarakat lokal. Potensi ekowisata yang bertujuan untuk konservasi avifauna masih minim dan belum dikenal sehingga dapat dikembangkan dengan pembuatan jalur pengamatan burung (birdwatching track). Tujuan dari penelitian adalah mendata jenis burung dan menginterpretasikan hasil sebagai data awal lokasi ekowisata dengan membuat jalur pengamatan burung (birdwatching track). Metode yang digunakan adalah jelajah untuk pendataan jenis burung dan pembuatan peta wisata untuk interpretasi jalur pengamatan burung. Hasil penelitian menunjukkan perjumpaan dengan 40 spesies burung dari 25 famili yang masingmasing dapat ditemukan baik secara kosmopolit maupun jarang pada jalur pengamatan. Birdwatching track yang dikembangkan memiliki 5 pos dengan spesifikasi (vegetasi, ketinggian, waktu tempuh) dan jarak tertentu untuk memberikan hasil perjumpaan burung yang bervariasi selama kegiatan pengamatan. Pengelolaan jalur birdwatching track bekerjasama dengan karang taruna dusun Tambak yang telah memiliki akses ke jalur pendakian puncak Gunung Lawu.
\end{abstract}

Kata Kunci: birdwatching track, konservasi, Tambak, burung

\begin{abstract}
Resort Pemangku Hutan (Forest Manager Resort) or RPH Tambak is one of the forests managed by Indonesian State Forestry Enterprise in the northern part of Lawu Mountain, Surakarta. RPH Tambak located in the Berjo village, in Ngargoyoso, Central Java. This area offers ecotourism attraction for locals and international tourists. The management of forest becomes the main focus with involvement from the locals and stakeholders. This area is a potential area for avian conservation although this area is still relatively unknown. Because of its virgin forest and natural landscape, RPH Tambak has the potential to become a birdwatching spot. The aim of this research is to gather data about local avian species, to interpret the initial data for ecotourism, and to make a birdwatching track. The research methods used in this research are by tracking, and surveying the local avian species to create a roadmap for birdwatching track. The finding of this research is there are 40 species of birds from 25 families living along as cosmopolite and rarely in the birdwatching track. The birdwatching track has 5 posts with different specifications (vegetation, altitude, and tracking time) and tracking distance to make various contact with local
\end{abstract}


avian species. The birdwatching track will be maintained by locals that has the access to the peak of the Lawu Mountain.

Keywords: Birdwatching tracking, conservation, Tambak, birds

\section{PENDAHULUAN}

Hutan konservasi merupakan kawasan yang memiliki ciri khas tertentu dengan pemeliharaan komposisi ekosistem tumbuhan dan satwa yang bertujuan untuk kepentingan kelestarian lingkungan jangka Panjang.Hutan konservasi memiliki manfaat sebagai pensuplai oksigen, reduksi kadar karbondioksida di udara, sebagai tempat peresapan air dan tempat hidup untuk satwa yang ada di alam (Pawar \& Rothkar, 2015). Hutan konservasi Tambak terletak di desa Berjo, Karanganyar, Jawa Tengah. Hutan ini terletak pada kaki gunung Lawu (Setiyawan, 2019). Hutan konservasi Tambak berada pada ketinggian $1500 \mathrm{~m}$ dpl dengan kisaran suhu 22-32 ${ }^{\circ} \mathrm{C}$. Hutan jenis pegunungan maupun dataran tinggi memiliki variasi vegetasi yang masih terjaga. Vegetasi merupakan habitat, penyedia sumber pakan, serta penyedia shelter bagi burung (Afif et al., 2018).

Kawasan hutan konservasi Tambak memiliki keanekaragaman jenis burung yang cukup banyak, beberapa jenis dilindungi dan endemik Jawa (Puspita Sari et al., 2015). Identifikasi burung dilakukan dengan pengamatan secara langsung dengan menggunakan alat bantu berupa binokuler yang lazim disebut birdwatching. Birdwatching atau birding mulai populer dan tumbuh dengan cepat. Pengamat burung harus memiliki pengetahuan, skill, maupun minat, namun bagi pemula yang belum familiar butuh interpretasi tertentu tentang pengenalan medan, lingkungan, data burung, dan jalur pengamatan. Birdwatching dengan interpretasi dapat menjadi sarana pentingnya kelestarian alam bagi pengunjung (Hasibuan et al., 2018).

Sebagian masyarakat sekitar lokasi konservasi menangkap burung di dalam kawasan baik untuk dipelihara sendiri maupun diperjualbelikan. Faktor ekonomi menjadi penyebab maraknya perburuan dan penangkapan, padahal tidak sedikit burung menjadi mati, cidera, stress, sakit dalam prosesnya. Pendekatan avitourism dalam bentuk birdwatching akan memberikan keuntungan nonmateri dan materi bagi masyarakat sekitar tanpa harus menghilangkan jenis burung di hutan (Afif et al., 2018). Avitourism adalah industri wisata yang berbasis lingkungan dengan melakukan pengamatan burung langsung pada habitatnya (Steven, Morrison, Arthur, et al., 2015). Kegiatan avitourism biasanya dilengkapi dengan data burung-burung yang memiliki daya tarik bagi pengunjung dan jalur-jalur yang dapat dikunjungi. Avitourism membuat lingkungan dan keanekaragaman dari hutan terjaga dan meningkatkan perekonomian dari masyarakat sekitar (Steven et al., 2015).

Lokasi hutan Konservasi Tambak berbatasan dengan Tahura KGPAA Mangkunagoro I air terjun Jumog dan Parang Ijo, perkebunan teh Kemuning, serta objek wisata Telaga Madirda akan memberikan akses mudah untuk dikunjungi. Tujuan dari penelitian ini adalah mendata jenis burung dan menginterpretasikan hasil sebagai data awal lokasi ekowisata dengan membuat jalur pengamatan burung (birdwatching track).

\section{METODE PENELITIAN}

Penelitian ini merupakan penelitian deskriptif melalui observation technique. Metode pengumpulan data melalui pengamatan secara langsung di lokasi penelitian. Kegiatan penelitian dilakukan pada bulan April sampai Agustus 2018 di kawasan hutan konservasi 
Tambak. Pengamatan dilakukan pada pagi hari mulai pukul 06.00 - 10.00 WIB dan sore mulai pukul 14.30 - 17.30 WIB. Metode pengambilan data burung dengan menggunakan metode jelajah. Metode jelajah dilakukan dengan cara menentukan pos pengamatan dan jalur pengamatan, kemudian burung diamati sepanjang jalur dan dicatat burung-burung yang dijumpai (Paramita et al., 2015). Metode yang digunakan untuk membuat peta adalah observasi langsung. Pada penelitian ini, observasi secara langsung untuk melakukan pengecekan kebenaran data, yaitu jalur pengamatan burung dan lokasi pos pengamatan burung yang kemudian diplotkan menggunakan GPS. Pembuatan peta dilakukan dengan menggunakan aplikasi corel draw versi 7 berlisensi, untuk memberikan gambaran peta birdwatching track yang diinginkan.

Alat yang digunakan berupa teropong / binokuler merk Nikon Monarch 512 x 42 Binocular dan Bushnell Legacy $8 \times 42 \mathrm{~mm}$, kamera prosumer Sony DSC H400, kamera DSLR Nikon d3200 dan lensa nikon tele 18-300 mm, kamera Canon powershot SX60 HS, buku panduan lapang burung- burung SKJB (Sumatera Kalimantan Jawa dan Bali) karangan John Mackinon, penanda waktu, tally sheet, GPS, papan jalan, dan alat tulis. Obyek yang diamati berupa burung yang beraktivitas di kawasan hutan konservasi.

\section{HASIL DAN PEMBAHASAN}

1. Data Burung dari Metode Jelajah

Sebagai salah satu komponen ekosistem, burung dapat menjadi indikator lingkungan dari segi kelayakan dan daya dukung kehidupan karena mempunyai hubungan timbal balik dan saling menguntungkan dengan lingkungan (Paramita et al, 2015). Setiap jenis burung pada dasarnya berafiliasi dengan tipe vegetasi dan habitat yang digemari dan spesifik. Keberadan hutan memiliki peran penting untuk suplai makanan dan shelter. Data hasil pengamatan diambil pada berbagai ketinggian, tipe vegetasi dan kemiringan kemudian diinterpretasikan sebagai jalur pengamatan burung "birdwatching track".

Tabel 1. Jenis-jenis burung yang ditemui di hutan konservasi Tambak

\begin{tabular}{llllll}
\hline No. & Spesies & Nama Latin & English & Famili & $\begin{array}{l}\text { Status } \\
\text { Konservasi } \\
\text { (IUCN) }\end{array}$ \\
\hline 1 & Cucak Kutilang & Pycnonotus aurigaster Vieillot, 1818 & Sooty-headed bulbul & Pycnonotidae & LC \\
\hline 2 & Bondol Jawa & Lonchura leucogastroides, Moore, 1858 & Javan munia & Estrildidae & LC \\
\hline 3 & Bondol Peking & Lonchura punculata Linnaeus, 1758 & Scaly-breasted munia & Estrildidae & LC \\
\hline 4 & Wiwik Uncuing & Cacomantis sepulcralis S. Muller, 1843 & Rusty-breasted cuckoo & Cuculidae & LC \\
\hline 5 & Wiwik Kelabu & Cacomantis merulinus Scopoli,1786 & Plaintive cuckoo & Cuculidae & LC \\
\hline 6 & Walet Linchi & Collocalia linchi Horsefield $\&$ Moore & Cave swiflet & Apodidae & NT \\
\hline 7 & Cabai Jawa & Dicaeum trochileum Sparrman,1789 & $\begin{array}{l}\text { Scarlet-headed } \\
\text { flowerpecker }\end{array}$ & Dicaeidae & LC \\
\hline 8 & Cekakak Jawa & Halcyon cyanoventris Vieillot, 1818 & Javan kingfisher & Halcyonidae & LC \\
\hline 9 & Cekakak Sungai & Todiramphus chloris Boddaert,1783 & Collared kingfisher & Alcedinae & LC \\
\hline 10 & Caladi Ulam & Dendrocopos analis Bonaparte 1850 & $\begin{array}{l}\text { Freckle-breasted } \\
\text { woodpacker }\end{array}$ & Picidae & LC \\
\hline 11 & Caladi Tilik & Dendrocopos moluccensis Gmellin 1788 & Sunda pygmy woodpacker & Picidae & NT \\
\hline 12 & Sepah Hutan & Pericrocotus flammeus J.R Forster 1781 & Scarlet minivet & Campephagidae & LC \\
\hline 13 & Tepekong Jambul & Hemiprocne longipennis Rafinesque 1802 & Grey-rumped treeswift & Hemiprocnidae & LC \\
\hline 14 & Elang Hitam & Ictinaetus malayensis Temminck, 1822 & Black eagle & Accipitridae & LC \\
\hline 15 & Alap - Alap Kawah & Falco peregrinus Tunstall,1771 & Peregrine falcon & Falconidae & LC \\
\hline
\end{tabular}




\section{TECHNO: Vol. 09 (01) Mei 2020}

\begin{tabular}{|c|c|c|c|c|c|}
\hline 16 & Bentet Kelabu & Lanius schach Linnaeus 1758 & Long -tailed shrike & Laniidae & $\mathrm{LC}$ \\
\hline 17 & Srigunting Kelabu & Dicrurus leucophaeus Vieillot, 1817 & Ashy drongo & Dicruridae & LC \\
\hline 18 & Sepah Kecil & $\begin{array}{l}\text { Pericrocotus cinnamomeus Linnaeus } \\
1766\end{array}$ & Small minivet & Campephagidae & $\mathrm{LC}$ \\
\hline 19 & Sikatan Belang & Ficedula wastermanni Sharpe, 1888 & Little pied flycatcher & Muscicapidae & $\mathrm{LC}$ \\
\hline 20 & Cica Koreng Jawa & Megalurus palustris Horsefield, 1821 & Striated grassbird & Sylviidae & $\mathrm{LC}$ \\
\hline 21 & Anis Sisik & Zoothera dauma Latham,1790 & Scaly thrush & Turdidae & $\mathrm{LC}$ \\
\hline 22 & Ayam Hutan Hijau & Gallus varius Shaw, 1798 & Green junglefowl & Phasianidae & LC \\
\hline 23 & Uncal Loreng & Macropygia unchall Wagler, 1827 & Barred cuckoo - dove & Columbidae & NT \\
\hline 24 & Kepudang Sungu Jawa & Coracina javensis Horsefield, 1821 & Javan cuckooshrike & Campephagidae & $\mathrm{LC}$ \\
\hline 25 & Gelatik Batu Kelabu & Parus major Linnaeus 1758 & Cinereous Tit & Paridae & $\mathrm{LC}$ \\
\hline 26 & Sikatan Ninon & Eumyias indigo Horsefield, 1821 & Indigo flaycatcher & Muscicapidae & $\mathrm{LC}$ \\
\hline 27 & Sepah Gunung & Pericrocotus miniatus Temminck, 1822 & Sunda Minivet & Campephagidae & $\mathrm{LC}$ \\
\hline 28 & Kekep Babi & Artamus leucorynchus Linnaeus, 1771 & $\begin{array}{l}\text { White-breasted } \\
\text { woodswallow }\end{array}$ & Artamidae & $\mathrm{LC}$ \\
\hline 29 & Srigunting Hitam & Dicrurus macrocercus Vieillot, 1817 & Black Drongo & Dicruridae & LC \\
\hline 30 & Burung Gereja Erasia & Passer montanus Linnaeus, 1758 & Eurasian tree sparrow & Passeridae & $\mathrm{LC}$ \\
\hline 31 & Prenjak Padi & Prinia inornata Sykes, 1832 & Plain prinia & Cisticolidae & $\mathrm{LC}$ \\
\hline 32 & Tekukur Biasa & Streptopelia chinensis Scopoli, 1786 & Spotted dove & Columbidae & $\mathrm{LC}$ \\
\hline 33 & Kerak Kerbau & Acridotheres javanicus Cabanis, 1851 & Javan myna & Sturnidae & $\mathrm{LC}$ \\
\hline 34 & Wiwik Lurik & Cacomantis sonneratii Latham, 1790 & Banded bay cuckoo & Cuculidae & $\mathrm{LC}$ \\
\hline 35 & Pelatuk Kijang & Celeus brachyurus Vieillot, 1817 & Rufous woodpacker & Picidae & $\mathrm{LC}$ \\
\hline 36 & Unchal Buau & Macropygia emiliana Bonaparte, 1854 & Ruddy Cuckoo-dove & Columbidae & $\mathrm{LC}$ \\
\hline 37 & Perkutut Jawa & Geopelia striata Linnaeus, 1766 & Zebra Dove & Columbidae & $\mathrm{LC}$ \\
\hline 38 & Kacamata Biasa & Zosterops palpebrosus Temminck, 1824 & Oriental White-eye & Zosteropidae & $\mathrm{LC}$ \\
\hline 39 & Elang Ular Bido & Spilornis cheela Latham, 1790 & Crested Serpent Eagle & Accipitridae & $\mathrm{LC}$ \\
\hline 40 & Takur Ungkut Ungkut & $\begin{array}{l}\text { Megalaima haemacephala Statius Muller, } \\
1776\end{array}$ & Coppersmith Barbet & Ramphastidae & LC \\
\hline
\end{tabular}

Keterangan: LC (Least Concern) : berresiko rendah, NT (Near Threatened) : hampir terancam

Berdasarkan hasil pendataan yang telah dilakukan didapatkan daftar burung sebanyak 40 spesies, 25 famili, dan 9 ordo (Passeriformes, Cuculiformes, Apodiformes, Coraciiformes, Piciformes, Accipitriformes, Falconiformes, Galliformes, Columbiformes). Data jenis burung menggambarkan komposisi, jenis umum, endemisitas, serta potensi avifauna. Status konservasi mengacu pada Peraturan Menteri Kehutanan dan lingkungan hidup Republik Indonesia (Kementerian Lingkungan Hidup dan Kehutanan, 2018; Kementrian Lingkungan Hidup dan Kehutanan, 2018a, 2018b) Ictinaetus malayensis Temminck, 1822, Spilornis cheela Latham, 1790, Falco peregrinus Tunstall ,1771 merupakan burung yang dilindungi, sedangkan sisanya merupakan kelompok burung yang tidak dilindungi. Ictinaetus malayensis Temminck, 1822 (elang hitam) tampak sangat besar saat terbang, sering berpasangan. Ketika pagi sekitar jam 08.00 WIB sering terlihat meluncur dengan indah di sisi bukit, melakukan soaring di atas pemukiman, perkebunan, yang kemudian hilang menuju sisi bukit yang lain. Elang ular bido (Spilornis cheela Latham, 1790) memiliki ukuran yang bervariasi, penyendiri, bentuk sayap pendek, bulat dan lebar. Ciri khas yang membedakan dengan elang hitam adalah terdapat garis tebal putih pada ekor dan garis putih panjang pada sayap yang sangat jelas saat terbang, sering mengeluarkan suara saat terbang: pi-pi-wheeeah-wheeah (Mackinnon., et al, 2010). Alap-alap kawah memiliki tipe sama dengan elang hitam, dengan kecepatan terbang relatif 
lebih cepat dibanding elang hitam. Kondisi ujung sayap saat terbang membedakan elang hitam yang "menjari" dan alap-alap kawah yang menyatu.

Burung endemik Jawa juga dijumpai di jalur pengamatan diantaranya adalah: cekakak jawa (Halcyon cyanoventris Vieillot,1818) ukuran tubuh sekitar $25 \mathrm{~cm}$, termasuk kelompok pemakan ikan (kingfisher), memiliki paruh yang panjang, sering dijumpai hinggap di bebatuan pinggir sungai atau telaga untuk mencari makan. Kepudang sungu jawa (Coracina javensis Horsefield, 1821) jenis burung ukuran besar berwarna abu-abu dengan sisi bulu sayap berwarna putih, secara umum tinggal di puncak pohon tertinggi maupun di pinggiran bekas tebangan hutan. Cabai jawa (Dicaeum trochileum Sparrman,1789) berukuran kecil berwarna hitam dan merah menyala, sering mengunjungi lahan terbuka maupun rumpun benalu untuk mengambil buah benalu yang lengket, biasa dijumpai dalam keadaan soliter atau kelompok kecil. Ayam hutan hijau (Gallus varius Shaw, 1798) dijumpai secara berpasangan, habitat di semak tepi hutan, mengkonsumsi serangga dan biji-bijian. Bondol jawa (Lonchura leucogastroides, Moore, 1858) mudah dijumpai, ukurannya kecil dominan warna hitam, putih dan coklat, sering berkelompok dan membaur dengan jenis bondol lainnya. Cica koreng jawa (Megalurus palustris Horsefield, 1821) memiliki ukuran agak besar, tubuh berwarna coklat dengan garis tebal hitam di punggung, sering dijumpai di daerah rumpun bambu, bertengger di pucuk pohon maupun di daerah perkebunan teh sampai ketinggian 2000 mdpl. Perkutut jawa (Geopelia striata Linnaeus, 1766) menyukai ladang dan hutan terbuka di dekat pemukiman penduduk, sudah semakin jarang di temui karena maraknya perburuan untuk perdagangan.

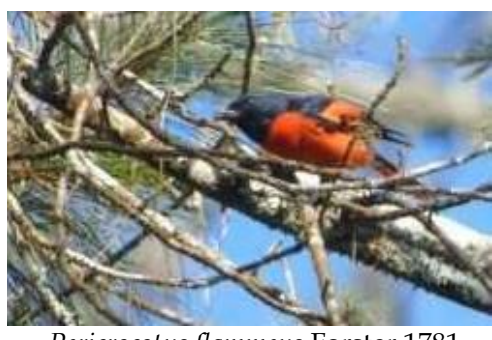

Pericrocotus flammeus Forster 1781

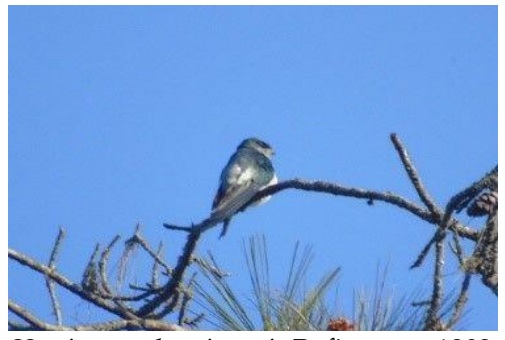

Hemiprocne longipennis Rafinesque 1802
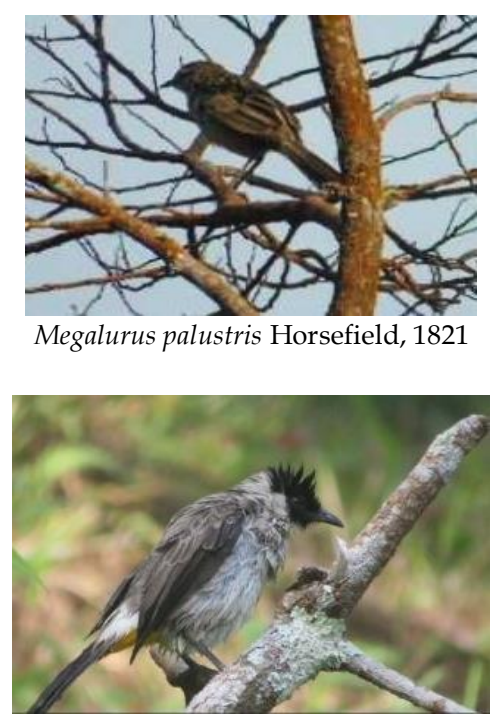

Pycnonotus aurigaster Vieillot, 1818

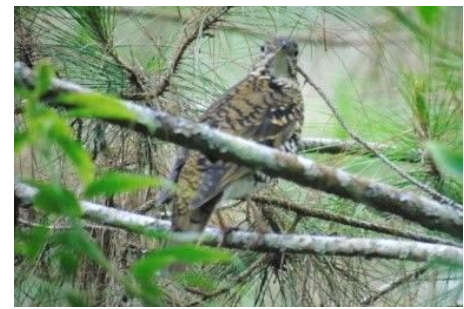

Zootera dauma Latham,1790

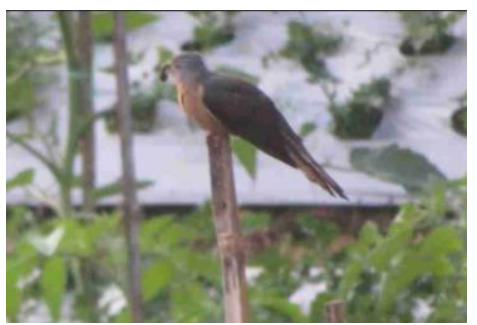

Cacomantis merulinus Scopoli,1786

Gambar 1. Sebagian jenis burung yang ditemukan di kawasan hutan konservasi Tambak (Foto : Siti Fadzillah, Dewi Puspita Sari, Ivananda Rennar Sari)

\section{Peta birdwatching track}

Lima pos pengamatan burung sebagai titik henti dalam pengamatan memiliki titik koordinat sebagai berikut:

Tabel 2. Koordinat pos pengamatan burung di jalur Birdwatching track

\begin{tabular}{cc}
\hline Pos & Titik Koordinat \\
\hline I & $7^{\circ} 38^{\prime} 14^{\prime \prime} \mathrm{S}$ dan $111^{\circ} 08^{\prime} 13^{\prime \prime} \mathrm{E}$ \\
\hline $\mathrm{II}$ & $7^{\circ} 38^{\prime} 19^{\prime \prime} \mathrm{S}$ dan $111^{\circ} 08^{\prime} 31^{\prime \prime} \mathrm{E}$ \\
\hline
\end{tabular}


TECHNO: Vol. 09 (01) Mei 2020

\begin{tabular}{cl}
\hline III & $7^{\circ} 38^{\prime} 29^{\prime \prime} \mathrm{S}$ dan $111^{\circ} 08^{\prime} 41^{\prime \prime} \mathrm{E}$ \\
\hline $\mathrm{IV}$ & $7^{\circ} 38^{\prime} 29^{\prime \prime} \mathrm{S}$ dan $111^{\circ} 08^{\prime} 29^{\prime \prime} \mathrm{E}$ \\
\hline $\mathrm{V}$ & $7^{\circ} 38^{\prime} 35^{\prime \prime} \mathrm{S}$ dan $111^{\circ} 07^{\prime} 57^{\prime \prime} \mathrm{E}$ \\
\hline
\end{tabular}

Berdasarkan titik koordinat masing-masing pos kemudian ditarik garis yang saling menghubungkan berdasarkan rekam jejak ketika melakukan survey dengan menggunakan GPS sehingga menjadi jalur pengamatan burung di kawasan hutan konservasi Tambak Ngargoyoso. Panjang track dari start sampai ke Telaga Madirda adalah 3,8 km dengan waktu tempuh 2 jam. Pada masing-masing pos dapat dijumpai jenis burung yang beragam. Pada pos 1 terdapat 25 jenis burung, pos 2 terdapat 17 jenis burung, pos 3 terdapat 8 jenis burung, pos 4 terdapat 16 jenis burung, dan pos 5 terdapat 13 jenis burung. Peta birdwatching track lebih lanjut disajikan pada Gambar 2.

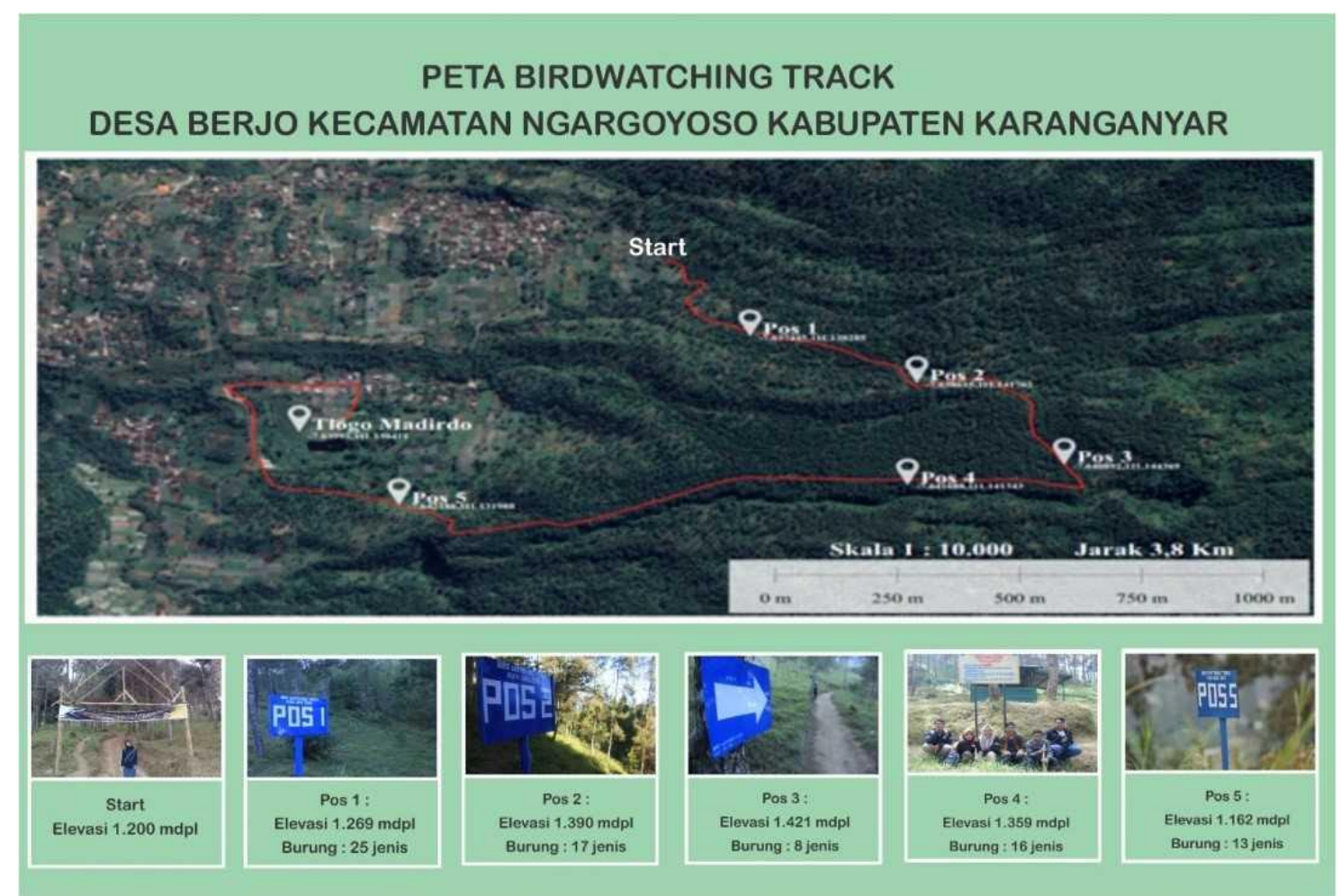

Gambar 2. Peta Birdwatching Track Desa Berjo Kecamatan Ngargoyoso Kabupaten Karanganyar (peta: Wahyu Trianingsih)

Pos 1 merupakan pos pertama dimulai pengamatan. Titik start berada di pinggir pemukiman yang berbatasan langsung dengan jalur Pendakian Tambak. Tanaman budidaya penduduk seperti buah- buahan, cengkeh, bunga mawar, pisang mendominasi, kemudian berbatasan dengan area budidaya hortikultura seperti kol, bawang merah, bawang putih, kubis, buncis, kapri, tomat, dan wortel. Pos 1 berakhir pada area hutan Pinus yang berbatasan dengan camping ground. Pos 2 merupakan daerah dengan elevasi yang agak curam, pada lokasi ini dijumpai jalur trail yang menghubungkan start jalur pendakian dan puncak Lawu. Vegetasi yang ada adalah pohon puspa dan pinus. Lokasi ini juga dijumpai sungai musiman yang akan terisi air jika musim hujan tiba. Pos 3 merupakan daerah punggungan yang memiliki tingkat vegetasi kurang rapat, terdiri dari pohon pinus dan dijumpai pos pemantau hutan dari PERHUTANI. Pos 4 merupakan daerah yang menyisir punggungan terdiri dari jalan setapak dengan kontur yang rapat dan menyempit menyisir sungai musiman. Pos 5 merupakan 
daerah yang berada di dekat objek wisata Telaga Madirda, jenis tanaman yang dijumpai adalah bambu, pinus, dan ladang sayur penduduk. Birdwatching track berakhir di Telaga Madirda.

\section{Afiliasi Vegetasi dan Tipe Habitat terhadap Perjumpaan dan Aktivitas Avifauna}

Habitat yang ideal di dalamnya mengandung bermacam macam sumber pakan, memungkinkan memiliki jenis burung yang relatif banyak (Adelina, et al., 2016). Vegetasi yang dijumpai dikategorikan menjadi tiga habitat, pertama adalah lahan terbuka dengan pertanian, hutan produksi pinus, lahan terbuka di telaga atau sumber air. Bervariasinya habitat dan vegetasi memberikan gambaran komposisi avifauna Hutan Konservasi Tambak. Komposisi avifauna pada berbagai pos jalur pengamatan ditampilkan pada gambar 3 .

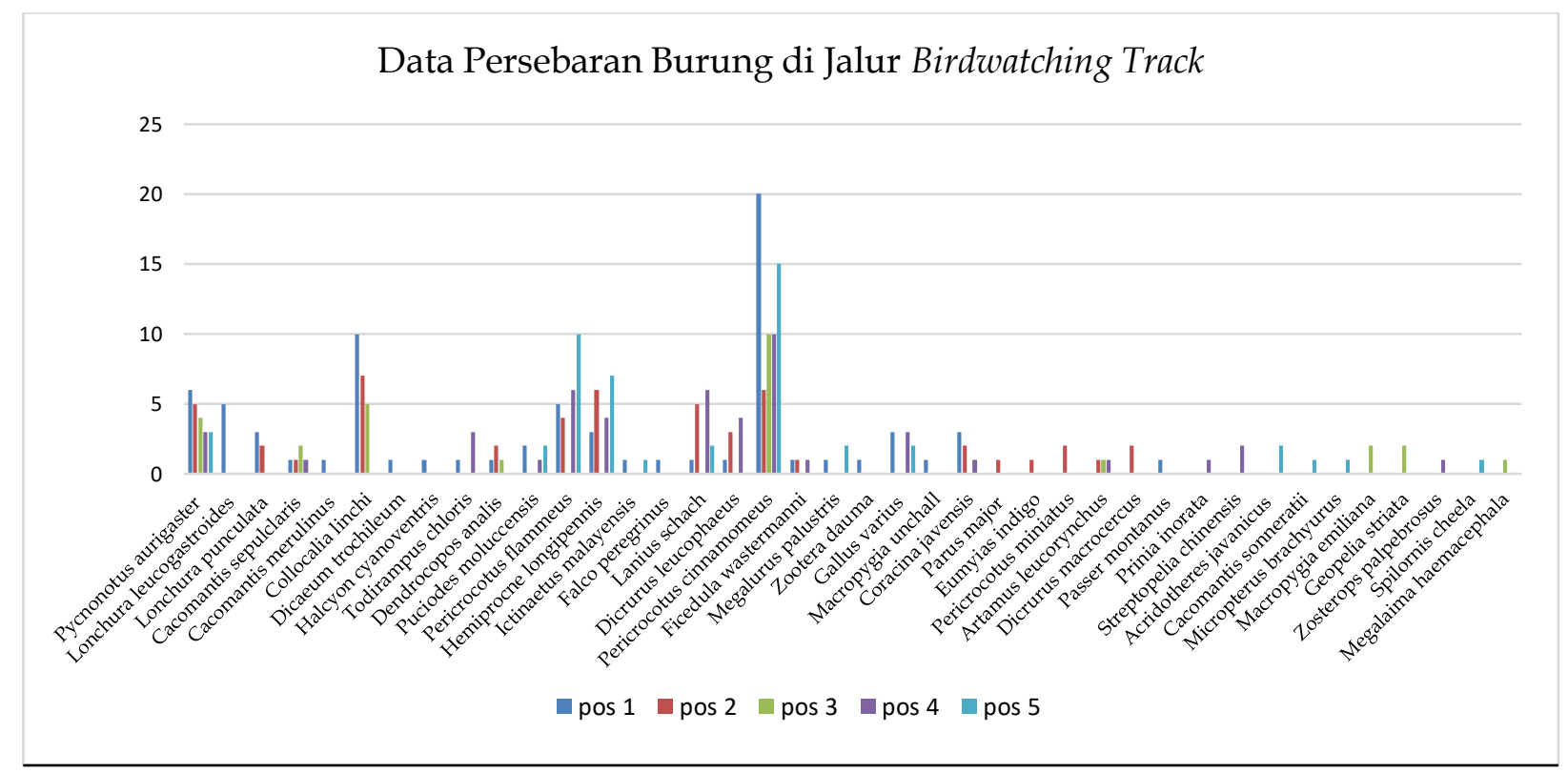

Gambar 3. Persebaran jenis Burung pada Birdwatching Track di Hutan Konservasi Tambak

Birdwatching track menyajikan 5 pos yang memiliki karakteristik vegetasi yang berbeda. Berdasarkan Gambar 3 beberapa jenis burung dijumpai dalam jumlah yang sering di berbagai pos serta jenis avifauna lain dijumpai dalam jumlah yang sedikit dan spesifik di pos tertentu. Burung yang sering ditemui adalah tepekong jambul (Hemiprocne longipennis Rafinesque 1802), wiwik uncuing (Cacomantis sepulcralis S. Muller, 1843), wallet linchi (Collocalia linchi Horsefield \& Moore 1854), sepah hutan (Pericrocotus flammeus J.R Forster 1781), sepah kecil (Pericrocotus cinnamomeus Linnaeus 1766), Bentet kelabu (Lanius schach Linnaeus 1758), dan cucak kutilang (Pycnonotus aurigaster Vieillot, 1818). Cucak kutilang merupakan jenis burung yang memiliki perjumpaan hampir di semua pos, ciri morfologinya memiliki topi hitam dengan tunggir putih dan tungging kuning- jingga, ekor warna coklat, sayap hitam, dada dan perut putih. Burung ini mudah dijumpai pada hampir semua tipe habitat, tempat terbuka, hutan sekunder sampai ketinggian $1600 \mathrm{mdpl}$, pekarangan termasuk pemukiman. Sepah hutan dan sepah kecil merupakan jenis kelompok burung yang paling sering dijumpai. Para pengamat pemula biasanya kurang familiar dengan burung ini dan sulit untuk membedakan spesies maupun jantan dan betina karena mereka sering berkumpul dalam jumlah banyak. Sepah hutan (Pericrocotus flammeus J.R Forster 1781) jantan memiliki ciri khas berukuran 17-22 $\mathrm{cm}$ berwarna biru kehitaman dengan dada, perut, tungging, sisi terluar bulu ekor dan bercak 


\section{TECHNO: Vol. 09 (01) Mei 2020}

pada sayap merah. Betina memiliki warna lebih abu- abu pada punggung, warna merah diganti warna kuning yang melebar dari tenggorokan dagu, dahi, dan penutup telinga. Mangsa insekta (jenis lepidoptera dan ortoptera) dan arthropoda (kelompok arachnida). Sepah kecil (Pericrocotus cinnamomeus Linnaeus 1766) memiliki ukuran berkisar $16 \mathrm{~cm}$ dengan warna abu abu gelap, kuning jingga kemerahan dan putih kusam, menempati habitat semak belukar, lahan pertanian kadang mengunjungi pemukiman di pinggir hutan (Mackinnon et al., 2010). Tepekong Jambul (Hemiprocne longipennis Rafinesque 1802) sering dijumpai karena mobilitas yang tinggi, aktif pada pagi hari, dan memiliki suara yang khas sehingga menarik untuk diamati. Walet linchi sering terlihat terbang dalam jumlah banyak hampir di semua pos. Bentet kelabu sering mengunjungi daerah pertanian atau daerah perkebunan sayur, soliter, sering berdiam di tonggak kayu atau bertengger untuk mengamati mangsa, kemudian mendadak menyambar serangga yang sedang terbang.

Burung unik dengan perjumpaan yang jarang antara lain anis sisik (Zootera dauma Latham,1790), gelatik batu kelabu (Parus major Linnaeus 1758), sikatan ninon (Eumyias indigo Horsefield, 1821), srigunting hitam (Dicrurus macrocercus Vieillot, 1817), kerak kerbau (Acridotheres javanicus Cabanis, 1851), pelatuk kijang (Celeus brachyurus Vieillot, 1817), dan kacamata biasa (Zosterops palpebrosus Temminck, 1824). Selain itu terdapat beberapa burung yang dalam IUCN dinyatakan near threatened atau hampir terancam yakni walet linchi (Collocalia linchi Horsefield \&Moore 1854), caladi tilik (Dendrocopos moluccensis Gmellin 1788), dan unchal loreng (Macropygia unchall Wagler, 1827).

\section{Gambaran Avifauna di Lokasi Birdwatching track}

Birwatching track sampai Pos 1 dimulai dari perbatasan pemukiman penduduk sebagai titik start kemudian dilanjutkan dengan area lahan pertanian. Lahan pertanian menyajikan berbagai komposisi tanaman mulai dari cengkeh, kebun sayur (wortel, tomat, cabai, bawang putih, bawang merah, kapri, buncis, kol) serta beberapa tanaman budidaya berupa bunga mawar. Sumber air juga dijumpai di lokasi pertanian dan budidaya bunga. Menurut Sunarno (2019) keberadaan pohon pada beberapa lokasi pengamatan dapat digunakan sebagai shelter, pohon istirahat, dan lokasi sumber pakan. Data burung yang hadir di pos 1 memiliki jumlah paling banyak dibandingkan pos lainnya. Kondisi ini disebabkan karena lahan pertanian memberikan suplai serangga yang cukup banyak untuk burung bertipe karnivora dan omnivora. Selain itu, jumlah burung yang relative banyak memberikan gambaran bahwa beberapa jenis burung tidak mengalai gangguan dengan aktivitas manusia. Variasi jenis makanan lebih memiliki kecenderungan untuk memilih habitat ini (Muttaqien et al., 2015)

Jalur dari pos 1 hingga pos 2 memiliki vegetasi berupa puspa, akasia dan pinus. Komposisi dari avifauna mulai menurun dibanding pos 1, hal ini disebabkan karena pada pos 1 hingga pos 2 terdapat camping ground yang sudah banyak diintroduksi manusia, sehingga kehadiran manusia dimungkinkan dapat mengganggu jalur alami atau habitat alami burung untuk mencari pakan (Alwis et al., 2016). Pada jalur ini dijumpai beberapa jenis burung pemalu dan unik seperti srigunting hitam, gelatik batu dijumpai dalam jumlah yang kecil karena proses perburuan oleh masyarakat untuk diperdagangkan sebagai burung kicauan, menyebabkan penurunan populasi di alam (Tanalgo, et al, 2015). Jalur dari pos 2 hingga pos 3 berupa hutan pinus makin mengalami penurunan jenis burung. Menurut Rohiyan (2014), umumnya didominasi oleh tumbuhan bawah serta faktor lain seperti penebangan pohon alih fungsi hutan, menyebabkan jumlah burung sedikit ditemukan. Vegetasi yang kurang rapat dan dominasi tanaman memberikan peluang shelter dan sumber pakan yang terbatas untuk dieksplorasi oleh burung. 
Jalur dari pos 3 hingga pos 4 merupakan jalur yang menurun dengan vegetasi yang masih sama seperti pos 3 namun tutupan kanopi relatif lebih rapat ditambah dengan tanaman seling seperti Acacia deccurent dan semak belukar. Habitat semak belukar memberikan kesempatan untuk mengamati ayam hutan hijau yang sedang mencari makan. Pos 4 hingga pos 5 jalur yang paling indah karena lokasi telaga bisa terlihat dari pos ini. Vegetasi yang menyusun mulai beralih dari hutan pinus menjadi lahan yang dikelola masyarakat, pohon bambu, pisang, cengkeh mulai mendominasi. Jenis burung yang bisa diamati antara lain: cica koreng jawa (Megalurus palustris Horsefield, 1821) yang dijumpai di rumpun bambu (Mackinnon et al, 2010), kerak kerbau (Acridotheres javanicus Cabanis, 1851), dan pelatuk kijang (Celeus brachyurus Vieillot, 1817).

\section{Potensi Avitourism sebagai tool konservasi burung}

Avitourism merupakan suatu kegiatan wisata pengamatan burung yang dilakukan langsung di alam. Avitourism biasanya mengamati burung-burung yang unik baik pada perilaku, bentuk tubuh, warna tubuh, suara, dan habitat (Sunarno, 2019). Kawasan konservasi Tambak memiliki landscape yang indah, masyarakat yang ramah dengan kearifan lokal, suasana yang masih alami merupakan keunikan dan potensi yang layak dikembangkan. Pembangunan Kawasan wisata Telaga Madirda oleh Pemda Karanganyar memberikan peluang untuk berkembangnya ekowisata berbasis Avifauna. Endemisitas pada Kawasan yang khas memberikan tambahan nilai pada pengembangan avitourism (Aunurohim dan Aris, 2014). Dari data burung pada Tabel 1, diketahui terdapat beberapa burung yang memiliki suara dan bentuk unik ditemukan di kawasan hutan konservasi Tambak. Kondisi tersebut memberikan peluang avitourism di kawasan hutan konservasi Tambak untuk dikembangkan. Avitourism memberikan banyak kesempatan seperti pembelajaran dialam, sebagai sarana pembangunan berkelanjutan, menjaga kelestarian lingkungan, menciptakan lapangan kerja, dan memberi manfaat sosiokultur (Bhuiyana et al., 2010). Adanya burung dengan status hampir terancam juga memberikan daya tarik bagi wisatawan. Manfaat lingkungan adalah avitourism adalah kondisi ekologi dari suatu lingkungan dapat terjaga dengan baik. Manfaat bagi masyarakat adalah perekonomian daerah sekitar akan mengalami kemajuan seperti adanya fasilitas persewaan alat, pemandu wisata dan home stay untuk para wisatawan (Afif et al., 2018).

\section{KESIMPULAN}

Hasil penelitian menunjukkan perjumpaan dengan 40 spesies burung dari 25 famili dan 9 ordo yang masing-masing dapat ditemukan baik secara kosmopolit maupun jarang pada jalur pengamatan. Birdwatching track yang dikembangkan memiliki 5 pos dengan spesifikasi (vegetasi, ketinggian, waktu tempuh) dan jarak tertentu untuk memberikan hasil perjumpaan burung yang bervariasi selama kegiatan pengamatan. Kawasan konservasi Tambak dinilai cukup potensial untuk dikembangkan menjadi kawasan avitourism di Kecamatan Ngargoyoso

Kabupaten karanganyar melalui sinergi dengan masyarakat lokal. Pengelolaan jalur birdwatching track bekerjasama dengan karang taruna dusun Tambak yang telah memiliki akses ke jalur pendakian puncak Gunung Lawu.

\section{UCAPAN TERIMA KASIH}

Terimakasih kepada LPPM UNS untuk dana hibah P-KKN 2018 yang berjudul "Pemberdayaan Potensi Ekowisata Birdwatching Track dan Hortikultura (Sayur Siap Saji) di Kecamatan Ngargoyoso Karanganyar" dan Kepala PERHUTANI KPH Lawu Utara atas izin riset. 


\section{DAFTAR PUSTAKA}

Adelina, M, Harianto, S P., dan N. N. (2016). Keanekaragaman Jenis Burung Di Hutan Rakyat Pekon Kelungu Kecamatan Kotaagung Kabupaten Tanggamus. Jurnal Sylva Lestari, 4(2), 51-60.

Afif, F., Aisyianita, R. A., \& Saptin, D. S. (2018). Potensi Birdwatching Sebagai Salah Satu Daya Tarik Wisata Di Desa Wisata Jatimulyo, Kecamatan Girimulyo,Kabupaten Kulon Progo. Jurnal Media Wisata, 16(2), 1007-1015.

Alwis, N. S., Perera, P., \& Dayawansa, N. P. (2016). Response of tropical avifauna to visitor recreational disturbances: A case study from the Sinharaja World Heritage Forest, Sri Lanka. Avian Research, 7(1), 1-13. https://doi.org/10.1186/s40657-016-0050-5

Aunurohim dan Aris, S. (2014). Studi Keanekaragaman Avifauna Sebagai Sarana Edukasi Ekowisata. Jurnal Sains Dan Seni Pomits, 2(1), 1-5.

Bhuiyana, Md. Anowar Hossain, Rabiul Islama, Chamhuri Siwara, S. M. I. (2010). Educational Tourism and Forest Conservation : Diversification for Child International Conference on Learner Diversity 2010 Educational Tourism and Forest Conservation : Diversification for Child Education. Procedia Social and Behavioral Sciences, 7 (C)(May 2014), 19-23. https://doi.org/10.1016/j.sbspro.2010.10.003

Hasibuan, R. S., Nitibaskara, T. U., \& Mahardika, R. (2018). Jalur interpretasi “birdwatching" di Kebun Raya Bogor. Media Konservasi, 23(1), 28-36.

Kementerian Lingkungan Hidup dan Kehutanan Republik Indonesia. (2018). Peraturan Menteri Lingkungan Hidup dan Kehutanan Republik Indonesia No. P.106/MenLHK/Setjen/Kum.1/12/2018 tentang Perubahan Kedua atas Peraturan Menteri Lingkungan Hidup dan Kehutanan No.

P.20/MenLHK/Setjen/Kum.1/6/2018 tentang Jenis Tumbuhan dan Satwa ya (p. 30).

http://ksdae.menlhk.go.id/assets/news/peraturan/P.106-2018_JENIS_TSL_.pdf

Kementrian Lingkungan Hidup dan Kehutanan. (2018a). Menteri Lingkungan Hidup dan Kehutanan nomor P.92/MENLHK/SETJEN/KUM.1/8/2018 Tentang Perubahan atas Peraturan Menteri Lingkungan Hidup dan Kehutanan nomor P.20/MENLHK/SETJEN/KUM.1/6/2018 Tentang Jenis Tumbuhan dan Satwa yang Dilindungi (P.92/MENLHK/SETJEN/KUM.1/8/2018 tentang Perubahan Atas Peraturan Menteri Lingkungan Hidup dan Kehutanan Nomor P.20/MENLHK/SETJEN/KUM.1/6/2018 Tentang Jenis Tumbuhan dan Satwa Dilindungi; pp. 1-29).

http://ksdae.menlhk.go.id/assets/news/peraturan/Permen_LHK_No.92_Tahun_2018Perubahan_P_.20_TSL_dilindungi_.pdf.

http://ksdae.menlhk.go.id/assets/news/peraturan/Permen_LHK_No.92_Tahun_2018-

Perubahan_P_.20_TSL_dilindungi_.pdf

Kementrian Lingkungan Hidup dan Kehutanan. (2018b). Peraturan Menteri Lingkungan Hidup dan Kehutanan Nomor P.20/MENLHK/SETJEN/KUM.1/6/2018 Tentang Jenis Tumbuhan dan Satwa Yang Dilindungi. In Kementrian Lingkungan Hidup dan Kehutanan (pp. 1-29). http://ksdae.menlhk.go.id/assets/news/peraturan/P.20_Jenis_TSL_.pdf

Mackinnon j, Phillips K, and B. van B. (2010). Burung-burung di Sumatra, Jawa, Bali, dan Kalimantan. Bogor: Puslitbang Biologi - LIPI/ Birdlife Indonesia.

Muttaqien, H. Z., Hakim, L., \& Leksono, A. S. (2015). Analysis of Bird Diversity for Supporting Ecotourism Development in Rajegwesi, Meru Betiri National Park. Journal of Indonesian Tourism and Development Studies, 3(3), 105-110. https://doi.org/10.21776/ub.jitode.2015.003.03.03

Paramita, E C, Kuntjoro S, A. R. (2015). Keanekaragaman dan Kelimpahan Jenis Burung di Kawasan Mangrove Center Tuban. Lentera Bio, 4(3), 150-154.

Pawar, K. V., \& Rothkar, R. V. (2015). Forest Conservation \& Environmental Awareness. Procedia Earth and Planetary Science, 11, 212-215. https://doi.org/10.1016/j.proeps.2015.06.027

Peterson, A..P. 2012. Zoonomen - Zoological Nomenclature Resource, 2006.04.08, website (version 08-Apr06). http://www.zoonomen.net

Puspita Sari, D., Karyanto, P., \& Muzayyinah, M. (2015). Studi Avifauna Gunung Lawu Berdasarkan Distribusi Altitudinal. Biogenesis: Jurnal Ilmiah Biologi, 3(2), 81-86.

https://doi.org/10.24252/bio.v3i2.931

Rohiyan, M., Setiawan, A., \& Rustiati, L. (2014). Keanekaragaman Jenis Burung di Hutan Pinus dan Hutan Campuran Muarasipongi Kabupaten Mandailing natal Sumatera Utara. Jurnal Sylva Lestari, 2(2), 89-98. 
Sari, D.P., S. Fadzillah, W. Trianingsih. 2020. birdwatching track, konservasi, Tambak, burung

Setiyawan, K. B. (2019). Social Capital in Community Forest Management: Case Study in Berjo Village Ngargoyoso, Karanganyar, Central Java. Jurnal Sosial Ekonomi Pertanian, 15(2), 156-163.

Steven, R., Morrison, C., Arthur, J. M., \& Castley, J. G. (2015). Avitourism and Australian important bird and biodiversity areas. PLoS ONE, 10(12), 1-11. https://doi.org/10.1371/journal.pone.0144445

Steven, R., Morrison, C., \& Castley, J. G. (2015). Birdwatching and avitourism: a global review of research into its participant markets, distribution and impacts, highlighting future research priorities to inform sustainable avitourism management. Journal of Sustainable Tourism, 23(8-9), 1257-1276. https://doi.org/10.1080/09669582.2014.924955

Sunarno, Rahadian, R., Wiradarma, H., Kurniawan, A., \& Tamar, I. M. (2019). The species diversity of avifauna in Bukit Cinta Klaten in supporting the development of birdwatching area of Gunung Gajah Village Klaten. Journal of Physics: Conference Series, 1217(1), 1-9. https://doi.org/10.1088/1742-6596/1217/1/012164

Tanalgo, K. Z, Pineda, John Arislyn Fuentes, Agravante, M. E. and, \& Amerol, Z. M. (2015). Bird Diversity and Structure in Different Land-use Types in Lowland South- Central Mindanao, Philippines. Tropical Life Sciences Research, 26(2), 85-103. 